INTERNATIONAL JOURNAL OF RESEARCHES IN BIOSCIENCES, AGRICULTURE \& TECHNOLOGY (C) VISHWASHANTI MULTIPURPOSE SOCIETY (Global Peace Multipurpose Society) R. No. MH-659/13(N) www.vmsindia.org

\title{
ENVIRONMENTAL HAZARD AND WASTE MANAGEMENT
}

${ }^{1}$ Fule U.W., ${ }^{1}$ Nimgare S.S. and ${ }^{2}$ Telkhade P.M.

\author{
${ }^{1}$ Hutatma Rasthriya Arts and Science College, Ashti, Wardha (M.S) India \\ ${ }^{2}$ Arts Commerce and Science College, Tukum, Chandrapur (M.S) India \\ Email: ujwalafule@gmail.com
}

\begin{abstract}
A modern hospital is a complex, multidisciplinary system which consumes thousands of items for delivery of medical care and is a part of physical environment. All these products consumed in the hospital leave some unusable left overs that is hospital waste. The last century witnesses the rapid mushrooming of hospital in the public and private sector, dictated by the needs of expanding population. The advent and acceptance of "disposable" has made the generation of hospital waste a significant factor in current scenario.
\end{abstract}

Keywords: Hospital wastes, Management, Environmental hazards and Disposal.

\section{Introduction:}

Hospital is a place of almighty, a place to serve the patient. Since beginning, the hospitals are known for the treatment of sick persons. Hospital waste is a potential health hazard to the health care workers, public and flora and fauna of the area. Hospital acquired infection, transfusion transmitted diseases, rising incidence of Hepatitis B, and HIV, increasing land and water pollution lead to increasing possibility of catching many diseases. Air pollution due to emission of hazardous gases by incinerator such as Furan, Dioxin, Hydrochloric acid etc. have compelled the authorities to think seriously about hospital waste and the diseases transmitted through improper disposal of hospital waste. This problem has now become a serious threat for the public health and, ultimately, the Central Government had to intervene for enforcing proper handling and disposal of hospital waste and an act was passed in July 1996 and a bio-medical waste (handling and management) rule was introduced in 1998. The rules are applicable to every institution generating hospital waste which includes hospital, nursing home, dispensary, veterinary institution, animal houses, pathological lab, blood bank etc.

An advance in medical facilities with the introduction of sophisticated instruments has increased the waste generation per patient in health care units (Radha, 2009). The waste is increasing day by day due to advances in scientific knowledge and has impact on human lives (Rao and Garg, 1994).The last century witnessed the rapid mushrooming of hospital in the public and private sector, dictated by the needs of expanding population. The advent and acceptance of "disposable" has made the generation of hospital waste a significant factor in current scenario.

\section{Classification of Hospital Waste}

(1) General waste: Largely composed of domestic or house hold type waste. It is non-hazardous to human beings, e.g. kitchen waste, packaging material, paper, wrappers, and plastics.

(2) Pathological waste: Consists of tissue, organ, body part, human fetuses, blood and body fluid. It is hazardous waste.

(3) Infectious waste: The wastes which contain pathogens in sufficient concentration or quantity that could cause diseases. It is hazardous e.g. culture and stocks of infectious agents from laboratories, waste from surgery, waste originating from infectious patients.

(4) Sharps: Waste materials which could cause the person handling it, a cut or puncture of skin e.g. needles, broken glass, saws, nail, blades, and scalpels.

(5) Pharmaceutical waste: This includes pharmaceutical products, drugs, and chemicals that have been returned from wards, have been spilled, are outdated, or contaminated.

(6) Chemical waste: This comprises discarded solid, liquid and gaseous 
chemicals e.g. cleaning, housekeeping, and disinfecting product.

(7) Radioactive waste: It includes solid, liquid, and gaseous waste that is contaminated with radionuclide's generated from in-vitro analysis of body tissues and fluid, in-vivo body organ imaging and tumor localization and therapeutic procedures.

Amount and composition of hospital waste generated

\section{(a) Amount}

$\begin{array}{ll}\begin{array}{l}\text { Country } \\ \text { (kg/bed/day) }\end{array} & \text { Quantity } \\ \text { U. K. } & \\ \text { U.S.A. } & 2.5 \\ \text { France } & 4.5 \\ \text { Spain } & 2.5 \\ \text { India } & 3.0 \\ \end{array}$

(b) Hazardous/non-hazardous

$\begin{array}{lr}\text { Hazardous } & 15 \% \\ \text { Hazardous but non-infective } & \\ \text { Hazardous and infective } & 10 \% \\ \text { Non-hazardous } & 85 \%\end{array}$

\section{(c) Composition}

By weight

a) Plastic

b) Combustible

c) Dry cellulosic solid

d) Wet cellulosic solid

$18 \%$

e) Non-combustible

$20 \%$

\section{Biomedical wastes}

Any solid, fluid and liquid or liquid waste, including its container and any intermediate product, which is generated during the diagnosis, treatment or immunization of human being or animals, in research pertaining thereto, or in the production or testing of biological and the animal waste from slaughter houses or any other similar establishment. All biomedical waste are hazardous. In hospital it comprises of $15 \%$ of total hospital waste.

\section{Rationale of hospital waste management}

Hospital waste management is a part of hospital hygiene and maintenance activities. In fact only $15 \%$ of hospital waste i.e. "Biomedical waste" is hazardous, not the complete. But when hazardous waste is not segregated at the source of generation and mixed with nonhazardous waste, then 100\% waste becomes hazardous.
Approach for hospital waste management Based on Bio-medical Waste (Management and Handling) Rules 1998, notified under the Environment Protection Act by the Ministry of Environment and Forest (Government of India).

\section{Segregation of wastes}

Segregation is the essence of waste management and should be done at the source of generation of Bio-medical waste e.g. all patient care activity areas, diagnostic services areas, operation theaters, labor rooms, treatment rooms etc. The responsibility of segregation should be with the generator of biomedical waste i.e. doctors, nurses, technicians etc. (medical and paramedical personnel). The biomedical waste should be segregated as per categories mentioned in the rules.

\section{Collection of bio-medical wastes}

Collection of bio-medical waste should be done as per Bio-medical waste (Management and Handling) Rules. At ordinary room temperature the collected waste should not be stored for more than 24 hours.

\section{Type of container and colour code for collection of bio-medical waste.}

\begin{tabular}{|c|c|c|c|}
\hline Category & Waste class & Type of container & Colour \\
\hline 1 & $\begin{array}{c}\text { Human anatomical } \\
\text { waste }\end{array}$ & Plastic & Yellow \\
\hline 2 & Animal waste & -do- & -do- \\
\hline 3 & $\begin{array}{c}\text { Microbiology and } \\
\text { Biotechnology waste }\end{array}$ & - do- & Yellow/Red \\
\hline 4 & $\begin{array}{l}\text { Waste sharp } \\
\text { Containers }\end{array}$ & $\begin{array}{c}\text { Plastic bag } \\
\text { puncture proof } \\
\text { Translucent }\end{array}$ & Blue/White \\
\hline 5 & $\begin{array}{l}\text { Discarded medicines } \\
\text { and Cytotoxic waste }\end{array}$ & Plastic bags & Black \\
\hline 6 & $\begin{array}{c}\text { Solid (biomedical } \\
\text { waste) }\end{array}$ & -do- & Yellow \\
\hline 7 & $\begin{array}{l}\text { Solid (plastic) } \\
\text { Containers }\end{array}$ & $\begin{array}{c}\text { Plastic bag } \\
\text { puncture proof }\end{array}$ & Blue/White \\
\hline 8 & Incineration waste & Plastic bag & Black \\
\hline & Chemical waste (solid) & -do- & -do- \\
\hline
\end{tabular}

\section{Transportation}

Within hospital, waste routes must be designated to avoid the passage of waste through patient care areas. Separate time should be earmarked for transportation of bio-medical waste to reduce chances of it's mixing with general waste. Desiccated wheeled containers, trolleys or carts should be used to transport the waste/plastic bags 
to the site of storage/ treatment. Hazardous biomedical waste needing transport to a long distance should be kept in containers and should have proper labels. The transport is done through desiccated vehicles specially constructed for the purpose having fully enclosed body, lined internally with stainless steel or aluminum to provide smooth and impervious surface which can be cleaned. The driver's compartment should be separated from the load compartment with a bulkhead. The load compartment should be provided with roof vents for ventilation.

\section{Treatment of hospital wastes}

- To disinfect the waste so that it is no longer the source of infection.

- To reduce the volume of the waste.

- Make waste unrecognizable for aesthetic reasons.

- Make recycled items unusable.

\section{$>$ General waste}

The $85 \%$ of the waste generated in the hospital belongs to this category. The, safe disposal of this waste is the responsibility of the local authority.

$>$ Bio-medical waste: $15 \%$ of Hospital wastes:

- Deep burial: The waste under category 1 and 2 only can be accorded deep burial and only in cities having less than 5 lakh populations. According to Rao (2008) in Maharashtra, Government, private hospitals and Nursing homes, there are about 35\% facilities of dumping of bio-medical waste.

- Autoclave and microwave treatment Standards for the autoclaving and microwaving are also mentioned in the Biomedical waste (Management and Handling) Rules 1998. All equipment installed/shared should meet these specifications. The waste under category $3,4,6,7$ can be treated by these techniques. Standards for the autoclaving are also laid down.

- Shredding: The plastic (IV bottles, IV sets, syringes, catheters etc.), sharps (needles, blades, glass etc) should be shredded but only after chemical treatment / microwaving / autoclaving. Needle destroyers can be used for disposal of needles directly without chemical treatment.

- Secured landfill:: The incinerator ash, discarded medicines, cytotoxic substances and solid chemical waste should be treated by this option.

- Incineration: The incinerator should be installed and made operational as per specification under the BMW rules 1998 and a certificate may be taken from CPCB/State Pollution Control Board and emission levels etc should be defined. In case of small hospitals, facilities can be shared. The polythene bags made of chlorinated plastics should not be incinerated.

\section{Safety measures}

$>$ All the generators of bio--medical waste should adopt universal precautions and appropriate safety measures while doing therapeutic and diagnostic activities and also while handling the bio-medical waste.

\section{$>$ It should be ensured that:}

- Drivers, collectors and other handlers are aware of the nature and risk of the waste.

- Written instructions, provided regarding the procedures to be adopted in the event of spillage/ accidents.

- Protective gears provided and instructions regarding their use are given.

- Workers are protected by vaccination against tetanus and hepatitis $B$.

\section{Training}

- Each and every hospital must have well planned awareness and training programmed for all categories of personnel including administrators (medical, paramedical and administrative).

- All the medical professionals must be made aware of Bio-medical Waste (Management and Handling) Rules 1998.

- To institute awards for safe hospital waste management and universal precaution practices.

- Training should be conducted to all categories of staff in appropriate language/medium and in an acceptable manner.

\section{Management and administration}

Heads of each hospital will have to take authorization for generation of waste from 
appropriate authorities as notified by the concerned State/U.T. Government, well in time and to get it renewed as per time schedule laid down in the rules. Each hospital should constitute a hospital waste management committee, chaired by the head of the Institute and having wide representation from all major departments. This committee should be responsible for making Hospital specific action plan for hospital waste management and its supervision, monitoring and implementation. The annual reports, accident reports, as required under BMW rules should be submitted to the concerned authorities as per BMW rules format.

\section{Measures for wastes minimization}

As far as possible, purchase of reusable items made of glass and metal should be encouraged. Select non PVC plastic items. Adopt procedures and policies for proper management of waste generated, the mainstay of which is segregation to reduce the quantity of waste to be treated. Establish effective and sound recycling policy for plastic recycling and get in touch with authorized manufactures.

\section{Coordination between Hospital and outside agencies}

- Municipal authority : As quite a large percentage of waste (in India up to $85 \%$ ), generated in Indian hospitals, belong to general category (non-toxic and nonhazardous), hospital should have constant interaction with municipal authorities so that this category of waste is regularly taken out of the hospital premises for land fill or other treatment.

- Co-ordination with Pollution Control Boards: Search for better methods technology, provision of facilities for testing, approval of certain models for hospital use in conformity with standards 'aid down.

- To search for cost effective and environmental friendly technology for treatment of bio-medical and hazardous waste. Also, to search for suitable materials to be used as containers for bio-medical waste requiring incineration/autoclaving/ microwaving.

\section{References:}

N. K. Dos, S. Prasad and K. Jayaram (20010: A TQM approach to implementation of handling and management o hospital waste in Tata main Hospital, Health Administrate, 11-12, 75-78

S. Gupta and R. Booth (2006): Report: Biomedical Waste management practices at.

Government of India. Biomedical waste (management and Handling) Rules. 1998. Extraordinary, part II, section 3, Subsection (ii). The gazette of India, no. 460, 27 July 1998.

Hem Chandra (1991): An Environmental Hazards and kits management, Hospital waste. Enviro news(3).

K. V. Radha, K. Kalaivani, R.A. Lavanya. case study of Biomedical waste management in hospitals, Global Journal of Health Science 2009;1:82-88.

P.H. Rao, (2008): Report: Hospital waste management awareness and practices: a study of three states in India. West management and Research, 26: 297-303. 